\title{
Factores relevantes en complicaciones de fracturas mandibulares. Relato de 5 años
}

\author{
Factors relevant to mandibular fracture complications. A five-year experience
}

Los autores nos presentan una revisión observacional, longitudinal y, en principio, prospectiva sobre un periodo de 5 años de los factores relevantes en las complicaciones del tratamiento quirúrgico de las fracturas mandibulares.

En el estudio se analiza la implicación de 10 "factores" en la aparición de complicaciones postoperatorias, como son, la edad, el sexo, la situación laboral, el abuso de drogas, la etiología del trauma, el tiempo en recibir tratamiento, el tipo de fractura, la complicación presentada y el tratamiento aplicado.

Del análisis del material y métodos no podemos concluir que se trate de un estudio prospectivo al desconocer la existencia de un cuestionario previo; más bien parece que los autores revisan las historias clínicas de los pacientes, anotando los datos referentes a estos diez factores analizados.

De los 472 pacientes que forman parte del estudio, el 11\% (54 pacientes), casi todos varones (82\%), presentó complicaciones que en la mitad de los casos requirieron hospitalización y nueva cirugía.

Aunque la causa más frecuente de fracturas de mandíbula son los accidentes de la vía pública (Brasileiro y cols. ${ }^{5}$ ), la serie de casos complicados estudiados tuvieron como causa etiológica mas relevante una agresión (35\%). Por lo general, depende en gran manera del área geográfica estudiada, siendo habitual que a mayor desarrollo económic sean más frecuentes las fracturas mandibulares por agresión, pasando a un segundo lugar , los accidentes de tráfico (bicicleta, motocicleta y automóvil); circunstancia que puede observarse en nuestro medio.

Está bien documentada la mayor incidencia de complicaciones en grupos a riesgo, como son los pacientes inmunodeprimidos, ADVP, (poli-) toxicómanos, pacientes con malos hábitos higiénicos y nutricionales. Así ocurre en el grupo estudiado, donde hay un alto consumo crónico de bebidas alcohólicas (48\% de los pacientes complicados) y un consumo de drogas del 18\%, muy similar a los datos obtenidos en su estudio por Passeri y cols. ${ }^{6}$.

Es frecuente considerar, de forma empírica, que ciertas circunstancias como la demora en solicitar atención médica por parte de estos pacientes (agresiones, estado de embriaguez, drogadicción, etc.) influyen en la aparición de complicaciones.

Por otro lado, no es raro que dicho tratamiento no pueda realizarse de forma precoz debido a la presencia de otros traumatismos asociados, a la presencia de daños multiorgánicos, etc. que someten al paciente a un estado de inestabilidad hemodinámica de tratamiento prioritario, retrasando el tratamiento definitivo de su fractura mandibular. ${ }^{4}$

En la serie estudiada por los autores, el $70 \%$ de los pacientes acudieron al Servicio en las 48 primeras horas tras el traumatismo. Parece pues, que la aparición de la complicación no está ínti-
The authors report an observational, longitudinal, and putatively prospective review of the factors related to complications of mandibular fracture surgery over a 5-year period.

The involvement of 10 factors in the occurrence of postoperative complications is analyzed, including age, gender, occupational status, drug abuse, etiology of the injury, time to treatment, type of fracture, complication, and treatment.

The analysis of the material and methods did not clarify whether it was a prospective study. It was not known if a previous questionnaire was used. The authors apparently reviewed the patients' medical records and recorded the data referring to the ten factors studied.

Of the 472 patients in the study, 11\% (54 patients), almost all men (82\%), experienced complications that required hospitalization and additional surgery in half of the cases.

The most frequent cause of jaw fractures is traffic accidents (Brasileiro et al. ${ }^{5}$, but the most relevant etiology in the series of complicated cases was assault (35\%). Generally speaking, the factors depended largely on the geographic area studied. In areas of greater economic development, mandibular fractures produced by assault were more frequent, with traffic accidents (bicycle, motorcycle, and automobile) passing to second place, as was observed in our study area.

The higher incidence of complications in groups at risk, such as immunocompromised patients, intravenous drug users, drug addicts (polydrug), and patients with poor personal hygiene and nutritional habits, is well documented. This was confirmed in the study group, in which there was a high rate of chronic alcohol use (48\% of patients with complications) and substance abuse (18\%), which was very similar to the data collected by Passeri et al. ${ }^{6}$

It is often thought that certain circumstances, such as delay in seeking medical care by patients (assault, drunkenness, substance abuse), influences the occurrence of complications.

On the other hand, it is not unusual that mandibular fractures cannot be treated early due to the presence of associated injuries, multiorgan damage, or other priority circumstances that affect the patient's hemodynamic instability and delay the definitive treatment of the mandibular fracture. $^{4}$ 
mamente relacionada con la demora en el tratamiento de la misma, según demuestra, además, en su estudio Jason y cols. ${ }^{1}$ contrariamente a la opinión de Champy y cols. ${ }^{2}$ y Cawood, ${ }^{3}$ que recomiendan no demorarse más de 12 a 24 h, respectivamente.

Estamos de acuerdo con los autores, y con la literatura, en que la infección es la complicación postquirúrgica más frecuente y más temida por el cirujano. Además, suele estar presente en el punto de partida de otras complicaciones 'menores' que condicionan un fracaso del tratamiento: exposición de la fijación, malunión, pseudoartrosis, etc. (34\% de incidencia en esta serie).

La complicación más frecuente, en este grupo, fue la infección; 32 pacientes la padecieron, lo que supuso casi un $60 \%$ de los casos complicados tras cirugía.

Un factor que sí se ha demostrado relevante en la aparición de infección postquirúrgica, es el abuso de sustancias como el alcohol.7 En pacientes con consumo crónico de alcohol se aprecia una evidencia histológica de la disminución de formación de hueso, respaldada por la disminución de calcitonina en suero, proteína secretada por los osteoblastos y marcador bioquímico de hueso en formación. ${ }^{1}$

También es frecuente la aparición de infecciones en pacientes que consumen drogas diariamente (tanto parenterales como no). Esto se debe a que estos pacientes presentan frecuentemente estados de malnutrición y tienen una pobre capacidad de respuesta ante las infecciones. ${ }^{6}$ En cuanto a los pacientes $\mathrm{VIH}+$, se ha visto que si tienen un recuento normal de CD4 no existe inmunosupresión y, por lo tanto, no padecen un mayor número de infecciones postquirúrgicas que la población normal. ${ }^{7}$

Otro factor que ha aumentado la aparición de infecciones postquirúrgicas en la cirugía de las fracturas mandibulares es el uso de técnicas de reducción abierta y fijación interna, frente a las técnicas de reducción cerrada, si bien las primeras tienen la ventaja de una mayor estabilización de la línea de fractura que optimiza la osificación con una mínima inmovilización mandibular.

El porcentaje de infección postquirúrgica utilizando técnicas de reducción abierta varía en un rango que va del $5 \%$ al $32 \%$ según los autores. ${ }^{8}$

Así mismo, estamos de acuerdo con los autores en que factores tales como la severidad del traumatismo y tipo de fractura influyen en el desarrollo de complicaciones postoperatorias, tales como la infección o la consolidación en malposición ya que su tratamiento es más complejo.

La posibilidad de contar con un grupo tan importante de pacientes con fracturas faciales proporciona la ocasión de verificar a fondo la influencia de los factores epidemiológicos concurrentes.

El diseño de este estudio retrospectivo lo consideramos inadecuado. Los datos no han sido manejados desde el punto de vista epidemiológico ni analizados de forma estadística para determinar la asociación significativa entre los diferentes factores estudiados y la aparición de complicaciones.

No se hace referencia a la localización de la fractura, dato importante ya que se sabe que las fracturas que se presentan en el ángulo mandibular son las que más complicaciones acarrean.

Lamentablemente, los autores no incluyen en el estudio el protocolo de tratamiento médico-quirúrgico establecido en esos pacientes y no podemos saber la cobertura antibiótica practicada, la técnica quirúrgica aplicada (cerrada o abierta: intraoral o extraoral), la
In the series studied by the authors, $70 \%$ of patients sought medical care in the 48 first hours after injury. Therefore, the occurrence of complications was not intimately related to delayed fracture treatment. This was also observed by Jason et al., ${ }^{1}$ and contradicts the opinion of Champy et al. ${ }^{2}$ and Cawood, ${ }^{3}$ who recommend not delaying treatment more than $12 \mathrm{~h}$ or $24 \mathrm{~h}$, respectively.

We agree with these and other authors that infection is the most frequent postoperative complication and the one most feared by surgeons. In addition, other "minor" complications usually are present at the start of treatment that can condition treatment failure: fixation plate exposure, malunion, pseudoarthrosis, and others (34\% in this series).

The most frequent complication in this group was infection; 32 patients suffered infection, including almost $60 \%$ of the patients with postoperative complications.

The abuse of substances like alcohol is a factor that has been shown to be relevant to the occurrence of postoperative infection. ${ }^{7}$ In patients with chronic alcohol use, histologic evidence is found of reduced bone formation. This is supported by diminished serum calcitonin, a protein that is secreted by osteoblasts and is biochemical marker of bone formation. ${ }^{1}$

The occurrence of infections in patients with daily substance abuse (parenteral or other) is common. These patients often suffer malnutrition and have a poor capacity to respond to infection. ${ }^{6}$ However, in HIV-positive patients it has been seen that if the CD4 count is normal, immunosuppression and postoperative infections are no more frequent than in the non-HIV population. ${ }^{7}$

Another factor that increases the incidence of postoperative infections in mandibular fracture surgery is the use of open reduction and internal fixation techniques, as opposed to closed reduction techniques. However, open techniques have the advantage of better stabilizing the fracture line, which optimizes ossification with minimal mandibular immobilization.

The postoperative infection rate using open reduction techniques ranges from $5 \%$ to $32 \%$ depending on the author. ${ }^{8}$

Likewise, we agree with the authors that factors like the severity of injury and type of fracture influence the development of postoperative complications like infection or impaired consolidation because the treatment is more complex.

The collection of such a large group of patients with facial fractures offers an opportunity to thoroughly verify the influence of concurrent epidemiologic factors.

However, we think that the design of this retrospective study is inadequate. The data were not managed epidemiologically or analyzed statistically to identify significant associations between the factors studied and the occurrence of complications.

No mention is made of the fracture location, which is important because it is known that mandibular angle fractures have more complications. 
presencia o no de bloqueo intermaxilar post-cirugía, el tiempo quirúrgico y la capacitación del profesional que realizó la cirugía. De esta forma es muy difícil concluir el efecto de todos estos factores en la aparición de la complicación postquirúrgica.

A pesar de que los autores indican que "las complicaciones postoperatorias fueron el punto central de este estudio", el análisis de las mismas nos parece de todo punto insuficiente y excesivamente superficial. Aparecen descritas complicaciones relacionadas con el abordaje quirúrgico (exposición del material de osteosíntesis y parálisis del nervio facial ¿definitiva?) sin que sepamos su magnitud en referencia al grupo de tratamiento. Un porcentaje de pacientes presentaron dos complicaciones pero no se nos indica cuales fueron, ya que podría ser interesante ver su asociación.

No están definidos los criterios para determinar la presencia de infección en el sitio de fractura (como son: inflamación, dolor, presencia de pus con o sin drenaje, signos de no-unión o mal-unión con dolor e inflamación).

En conclusión, los autores nos presentan una revisión retrospectiva de 5 años de los factores relevantes en las complicaciones del tratamiento quirúrgico de las fracturas mandibulares, que confirma los datos de la literatura actual al respecto y que se beneficiaría de una profundización epidemiológica para determinar la asociación significativa entre los diferentes factores estudiados en la aparición de complicaciones.

José I. Iriarte Ortabe Especialista en Estomatología, Cirugía Oral y Maxilofacial. Jefe del Servicio de Cirugía Oral y Maxilofacial, Hospital Son Dureta, Ib-Salut, Palma de Mallorca. España

Carmen Bosch Lozano

Especialista en Cirugía Oral y Maxilofacial. Médico Adjunto del Servicio de Cirugía Oral y Maxilofacial, Hospital Son Dureta, Ib-Salut, Palma de Mallorca. España
Unfortunately, the authors did not include the medical and surgical treatment protocol of the patients studied and we do not know what antibiotic coverage was used, the surgical technique (closed or open, intraoral or extraoral), the presence or absence of postoperative maxillomandibular fixation, surgical time, or the qualifications of the surgeon. It is very difficult to assess the contribution of these factors to the occurrence of postoperative complications in these circumstances.

Although the authors indicate that "postoperative complications were the focus point of this study", the analysis of these complications seems insufficient and overly superficial. Complications related to the surgical approach (fixation plate exposure and facial nerve paralysis, permanent?) are described but no information is given on their magnitude with respect to the treatment group. A percentage of patients had two complications, but no information is given on the specific complications, although it would be interesting to examine associations.

The criteria for determining the presence of fracture site infection are not defined (e.g., inflammation, pain, suppuration with or without drainage, and signs of nonunion or malunion with pain and inflammation).

In conclusion, the authors present a 5-year retrospective review of the factors contributing to complications in the surgical treatment of mandibular fractures that confirms the findings of the literature. It would benefit from more epidemiologic analysis to determine the significance of associations between the factors studied and the occurrence of complications.

\section{Bibliografía}

1. Biller JA, Pletcher SD, Goldberg AN, Murr AM. Complications and the time to repair of mandible fractures. The american laryngological, Rhinol Otol Soc 2005;115: 769-72.

2. Champy M, Lodde JP, Schmitt R, y cols. Mandibular osteosíntesis by miniature screwed plates via a buccal approach. J Oral Maxillofac Surg 1978;6:14-21.

3. Cawood JI. Small plate osteosynthesis of mandibular fractures. Br J Oral Maxillofac Surg 1985;23:77-91.

4. Press $B H$, Boies $L R J r$, Shons AR. Facial fractures in trauma victims: the influence of treatment delay on ultimate outcome. Ann Plast Surg 1983;11:121-4.

5. Brasileiro BF, Passeri LA. Epidemiological análisis of maxillofacial fractures in Brasil; A 5-year prospective study. Oral Surg Oral Med Oral Ptahol Oral Radiol Endod 2006;102: 28-34.

6. Passeri LA, Ellis E III, Sinn DP. Relationship of substance abuse to complications with mandibular fractures. J Oral Maxillofac Surg 1993;51:22-5.

7. Senel FC, Jessen GS, Melo MD, Obeid G. Infection following treatment of mandible fractures: the role of immunosuppression and polysubstance abuse. Oral Surg Oral Med Oral Ptahol Oral Radiol Endod 2007;103:38-42.

8. Maloney PL, Lincoln RE, Coyne CP. A protocol for the Management of compound mandibular fractures based on the time from injury to treatment. J OralMaxillofac Surg 2001;59:879-84. 